\title{
Effect of Modified Breakfast-Education for Type 2 Diabetes Mellitus: A Single-Center Randomized Clinical Trial
}

\author{
Cuiling Tong1, Hong Zhou ${ }^{1}$, Lin $\mathrm{Li}^{2}$ \\ ${ }^{1}$ Department of Nursing, Medical School of Yangtze University, Jingzhou, China \\ ${ }^{2}$ Department of Endocrinology, First People's Hospital of Jingzhou, Jingzhou, China \\ Email: 400167@yangtzeu.edu.cn
}

How to cite this paper: Tong, C.L., Zhou, H. and Li, L. (2018) Effect of Modified Breakfast-Education for Type 2 Diabetes Mellitus: A Single-Center Randomized Clinical Trial. Yangtze Medicine, 2, 154-160. https://doi.org/10.4236/ym.2018.23016

Received: June 10, 2018

Accepted: August 27, 2018

Published: August 30, 2018

Copyright (c) 2018 by authors and Scientific Research Publishing Inc. This work is licensed under the Creative Commons Attribution International License (CC BY 4.0).

http://creativecommons.org/licenses/by/4.0/

\section{cc) (i) Open Access}

\begin{abstract}
Objective: The effect of postprandial blood glucose (BG) by eating modified noodles and health education in type 2 diabetic mellitus (T2DM) patients was observed. Methods: To select T2DM patients who need therapies in hospital from June to September 2017 and divide the patients into study $(n=41$, Dried Noodles) and control ( $n=39$, Noodles with Soup) groups. After 3 months, the clinical/biochemical parameters and compliance of two groups were observed. Results: The study group has lower clinical/biochemical parameters and higher compliance than control group for 3 months of intervention. The difference between the two groups is statistically significant $(P<$ 0.05). Conclusion: The improvement of breakfast and health education mode effectively controls T2DM, promotes the development of good living habits of patients, and improves self-management ability and compliance of patients.
\end{abstract}

\section{Keywords}

Breakfast, Education, Type 2 Diabetic Mellitus

\section{Introduction}

Diabetes mellitus (DM), one of the major diseases, is affecting human health, which has become a growing concern in the world. The number of DM patients has increased from 108 million in 1980 to 422 million in 2014, with a prevalence rate of $4.7 \%$, rising to $8.5 \%$. As being estimated by International Diabetes Federation (IDF), there will be 592 million people that suffer from DM by 2035 [1] [2] [3], and about $90 \%$ of these affected patients are Type 2 Diabetes Mellitus (T2DM)

[2]. DM is a chronic disease with long-term and difficult therapeutic process, 
which often causes various acute and chronic complications such as diabetic nephropathy and diabetic foot [2] [3]. Therefore, it is important for patients to promote the self-management of DM [4]. Diet therapy and health education are the basis for the treatment of diabetes in the "Five carriages" [4]. Breakfast provides $20 \%$ - 35\% of the amount of daily energy requirements in diet therapy [3]. Therefore, the right way to eat breakfast could prevent patients from high BG after meals [1] [5]. However, the educational modes by words or pictures could not meet the needs of patients anymore [4]. The purpose of this clinical trial is to explore the effect of modified breakfast-education for T2DM patients.

\section{Patients and Methods}

\subsection{Patient Selection}

This study is approved by the Hospital Ethics Committee. All participants have signed informed consent before the study. The DM patients hospitalized in the Department of Endocrinology are chosen during the testing period from June 2017 to September 2017. The selection criteria are: 1) 18 - 80 years old; 2) According to the diagnostic criteria by American Diabetes Association (ADA) for T2DM in 2018 [6]; 3) The patients' conditions are suitable for using hypoglycemic drugs; 4) Participating in this study voluntarily. Exclusion criteria are: 1) Having diabetes during pregnancy; 2) With malignant tumors; 3) With severe liver and kidney or other organ diseases. Based on the results of the pre-test, the standard deviation was used to estimate the sample size. As a result, eighty-two patients are selected by convenience sampling method. According to the order of admission time, the subjects are divided into study and control group (41 cases in each group). In the control group, one of patients has hypoglycemic reactions and another one need the treatment of insulin pump due to high blood glucose (BG). Therefore, these two patients are excluded from this study. In the end, 39 cases are enrolled in the control group. There is no significant difference in baseline levels between the two groups (Table $1, P>0.05$ ).

\subsection{Breakfast-Education Improvement}

According to the Hattis-Benedict formula to calculate the Basal Energy Expenditure (BEE) for T2DM patients, the formula is as follows: $\mathrm{BEE}(\mathrm{male})=66.47+$ $13.75 \times$ weight $(\mathrm{Kg})+5.0 \times$ height $(\mathrm{cm})-6.76 \times$ age $(\mathrm{yrs})$, BEE $($ female $)=$ $655.10+9.56 \times$ weight $(\mathrm{Kg})+1.85 \times$ height $(\mathrm{cm})-4.68 \times$ age $(\mathrm{yrs})$ [7]. The unit

Table 1. Table comparison of general information.

\begin{tabular}{|c|c|c|c|c|c|}
\hline \multirow{2}{*}{ Group } & \multirow{2}{*}{$n$} & \multicolumn{2}{|c|}{$\operatorname{Sex}[n(\%)]$} & \multirow{2}{*}{$\begin{array}{c}\text { Age } \\
\left(\begin{array}{l}\bar{x} \pm s, \mathrm{yrs})\end{array}\right.\end{array}$} & \multirow{2}{*}{$\begin{array}{c}\text { Disease course } \\
(\bar{x} \pm s, \mathrm{yrs})\end{array}$} \\
\hline & & Male & Female & & \\
\hline Control & 39 & $23(61.5)$ & $15(38.5)$ & $56.05 \pm 8.39$ & $7.76 \pm 5.66$ \\
\hline Study & 41 & $18(46.3)$ & $22(53.7)$ & $56.34 \pm 12.46$ & $8.40 \pm 6.99$ \\
\hline$x^{2} / t$ & & \multicolumn{2}{|c|}{1.813} & -0.121 & -0.441 \\
\hline$P$ & & \multicolumn{2}{|c|}{0.182} & 0.904 & 0.661 \\
\hline
\end{tabular}


of BEE is Kilocalorie (Kcal). According to Chinese dietary guidelines, it is known that $188 \mathrm{~g}$ of cooked noodles have heat of $436 \mathrm{Kilo}$ Joules $(\mathrm{KJ})$ [8], as $2.32 \mathrm{KJ} / \mathrm{g}$. The amount of noodle $(\mathrm{g})=(\mathrm{BEE} \times 4.18 \mathrm{KJ}) / 2.32 \mathrm{KJ} \times 20 \%$. The patients in control group are given noodles having soup. On the contrary, the noodles in the study group do not contain soup. The noodles of standard meal made from wheat flour.

\subsection{Diabetes Education Model Improvement}

The control group had used the conventional model, such as diet guidelines, BG recording cards and so on [4]. The study group is based on from diverse culture backgrounds of their patients with their own features. The study group is based on the education of the control group, and used peer education additionally. The method of educational intervention is as follows: In this study, doctors, nurses and peer leader participate in the study group supervising and guiding other patients. Specific programs: 1) Responsible physicians invited patients who could use smartphones to join WeChat APP on DM's Blood Glucose Management (BGM), and select peer leader from older patients who have a high level of knowledge, good self-management skills, strong abilities and enthusiasm; 2) Two nurses supervise and co-lead the peer leader to complete the APP online training course. At the same time, the APP members are organized to conduct offline education activities; 3) Peer leader have completed online and offline training courses. After that, should help patients improve APP personal information, supervising monitor blood sugar, and organizing educational activities; 4) Patients need to record their 03:00, fasting blood-glucose (FBG) and two-hour postprandial blood glucose (2hPBG) in the APP. Meanwhile, patients have gotten diabetes knowledge, food calories and medication management through DM's BGM. The mode of modified breakfast- education has lasted 3 months in clinical, with breakfast intervention daily and peer education of three times a day.

\subsection{Assessment of Management Outcomes}

The examination of clinical and biochemical parameters, includes Body Mass Index (BMI), waist circumference, 03:00 BG, FBG, 2hPBG and HbA1c. Dinner time is controlled between 18:00 and 19:00 in both groups. BG is monitored at 03:00 on the next day (patients do not have meal for about 8 hours). FBG is monitored from 06:00 to 08:00. The compliance of patients in these two groups is compared after education intervention, including three aspects: monitoring BG, living rules and obeying doctor's orders. Those parameters and compliance were detected before and after intervention, and it took almost 5 days.

\subsection{Statistical Analysis}

SPSS 22.0 is used for the statistical analysis. 1) Baseline balance, such as sex, age and disease course is tested, if having no difference, and then the next study; 2) The comparison of numerical data is performed by $\mathrm{t}$ test. Quantitative variables are showed by chi-square test. $P<0.05$ is considered statistically significant. 


\section{Results}

\subsection{The Comparison of BG Levels before and after Intervention in Both Groups}

After the intervention, the parameters of the study group are better than the control group, the difference was statistically significant (Table 2, $P<0.05$ ).

\subsection{The Comparison of Compliance for Two Groups}

Patients in the study group have higher compliance than those in the control group (Table 3, $P<0.05$ ).

\section{Discussion}

The results in this study shows that modified breakfast -education modalities have done in the study group, whose clinical and biochemical parameters were lower than the control group, the difference is statistically significant $(P<0.05)$. At the same time, the patients' compliance is higher than the control group $(P<$ 0.05).

Parillo et al. [9] pointed out that BG is significantly lower than bread and potato flour after eating pasta. Ridner et al. [10] also certified that pasta made from durum wheat shows a lower Glycaemic Index (GI) than rice and pasta. The reason is that different forms of food have affected patients' digestibility [9] [11].

Table 2. Comparison of clinical and biochemical outcomes of two groups before and after intervention.

\begin{tabular}{|c|c|c|c|c|c|c|c|c|c|c|c|c|}
\hline \multirow{2}{*}{$\begin{array}{c}\text { Clinical/Biochemical } \\
\text { parameters }\end{array}$} & \multicolumn{2}{|c|}{ Control $(n=39)$} & \multirow[b]{2}{*}{$t$} & \multirow[b]{2}{*}{$P$} & \multicolumn{2}{|c|}{ Study $(n=41)$} & \multirow[b]{2}{*}{$t$} & \multirow[b]{2}{*}{$P$} & \multirow[b]{2}{*}{$t_{1}$} & \multirow[b]{2}{*}{$P_{1}$} & \multirow[b]{2}{*}{$t_{2}$} & \multirow[b]{2}{*}{$P_{2}$} \\
\hline & $\begin{array}{c}\text { Before } \\
\text { intervention }\end{array}$ & $\begin{array}{c}\text { After } \\
\text { intervention }\end{array}$ & & & $\begin{array}{c}\text { Before } \\
\text { intervention }\end{array}$ & $\begin{array}{c}\text { After } \\
\text { intervention }\end{array}$ & & & & & & \\
\hline BMI $\left(\mathrm{kg} / \mathrm{m}^{2}\right)$ & $25.83 \pm 2.06$ & $24.58 \pm 2.73$ & 2.279 & 0.025 & $25.84 \pm 1.30$ & $22.88 \pm 1.35$ & 10.108 & 0.000 & -0.027 & 0.978 & 3.548 & 0.001 \\
\hline Waist circumference $(\mathrm{cm})$ & $84.15 \pm 4.97$ & $81.48 \pm 4.72$ & 2.426 & 0.018 & $83.05 \pm 5.97$ & $78.02 \pm 5.73$ & 3.884 & 0.000 & 0.896 & 0.373 & 3.469 & 0.001 \\
\hline 03:00BG (mmol/L) & $8.45 \pm 2.29$ & $7.31 \pm 1.47$ & 2.604 & 0.011 & $7.93 \pm 1.90$ & $5.92 \pm 1.52$ & 5.284 & 0.000 & 1.095 & 0.277 & 4.165 & 0.000 \\
\hline FBG (mmol/L) & $8.41 \pm 2.55$ & $7.77 \pm 1.85$ & 1.265 & 0.210 & $8.46 \pm 1.71$ & $6.00 \pm 1.38$ & 7.155 & 0.000 & -0.100 & 0.920 & 4.846 & 0.000 \\
\hline $2 \mathrm{hPBG}(\mathrm{mmol} / \mathrm{L})$ & $12.53 \pm 3.11$ & $12.20 \pm 3.37$ & 0.450 & 0.654 & $12.58 \pm 2.70$ & $10.46 \pm 2.48$ & 3.698 & 0.000 & -0.08 & 0.936 & 2.636 & 0.010 \\
\hline HbAlc (\%) & $8.38 \pm 0.81$ & $7.69 \pm 0.89$ & 3.578 & 0.001 & $8.18 \pm 0.54$ & $6.07 \pm 0.96$ & 11.152 & 0.000 & 1.278 & 0.205 & 5.449 & 0.000 \\
\hline
\end{tabular}

The $t / P$ value of the control and study group refer to the comparison between pre-intervention and after the intervention in 3 months; The $t_{1} / P_{1}$ value refer to the comparison of two groups before the intervention; The $t_{2} / P_{2}$ value refer to the comparison of two groups after the intervention.

Table 3. Comparisons of compliance of two groups before and after intervention.

\begin{tabular}{|c|c|c|c|c|c|c|c|c|c|c|c|c|}
\hline \multirow[b]{2}{*}{ Compliances } & \multicolumn{2}{|c|}{ Control $(\mathrm{n}=39)$} & \multirow[b]{2}{*}{$\mathrm{x}^{2}$} & \multirow[b]{2}{*}{$P$} & \multicolumn{2}{|c|}{ Study $(\mathrm{n}=41)$} & \multirow[b]{2}{*}{$\mathrm{x}^{2}$} & \multirow[b]{2}{*}{$P$} & \multirow[b]{2}{*}{$x_{1}^{2}$} & \multirow[b]{2}{*}{$P_{1}$} & \multirow[b]{2}{*}{$x_{2}^{2}$} & \multirow[b]{2}{*}{$P_{2}$} \\
\hline & $\begin{array}{c}\text { Before } \\
\text { intervention }\end{array}$ & $\begin{array}{c}\text { After } \\
\text { intervention }\end{array}$ & & & $\begin{array}{c}\text { Before } \\
\text { intervention }\end{array}$ & $\begin{array}{c}\text { After } \\
\text { intervention }\end{array}$ & & & & & & \\
\hline Monitoring BG & $22(56.4)$ & $24(61.5)$ & 0.212 & 0.645 & $24(58.5)$ & $37(90.2)$ & 10.818 & 0.001 & 0.037 & 0.848 & 9.095 & 0.003 \\
\hline Living rules & $23(59.0)$ & $25(64.1)$ & 0.217 & 0.642 & $26(63.4)$ & $35(85.4)$ & 5.185 & 0.023 & 0.166 & 0.684 & 4.820 & 0.028 \\
\hline Obeying doctor's orders & $21(53.8)$ & $22(25.4)$ & 0.052 & 0.820 & $23(56.1)$ & $36(87.8)$ & 10.212 & 0.001 & 0.041 & 0.840 & 9.881 & 0.002 \\
\hline
\end{tabular}

The $x^{2} / P$ value of the control and study group refer to the comparison between pre-intervention and after the intervention in 3 months; The $x_{1}^{2} / P_{1}$ value refer to the comparison of two groups before the intervention; The $x_{2}^{2} / P_{2}$ value refer to the comparison of two groups after the intervention. 
When noodles are contact with water, their starch particles absorb moisture to expand the molecular chain, resulting in volume expansion. As the water temperature increasing, the starch granules continue to swell and dissolve into the water, forming viscous liquid. Cooked noodles continue immersion in warm soup could be gelatinized, being useful for digestion and absorption [12]. When the patients in control group have eaten loose noodles with soup, glucose is released into the blood quickly, leading to postprandial BG increase significantly. In the study group, cooked noodles being removed from hot soup is gradually cooling, and then degeneration of amylose in starch made the gelatinized starch from amorphous into crystalline state, not easily digested by amylase, and reducing the rate of digestion [12] [13]. Patients in the study group have eaten dry noodles, which would be harder to chew through the teeth. Therefore, this kind of noodles should be mechanical grinded by stomach, which extends the time of digesting and absorbing; Meanwhile, the speed of the release of glucose into the bloodstream slows down, and increasing postprandial BG is slow as well. At the same time, dry noodles impede the penetration of digestive enzymes into the starch, reducing the rate of starch degradation and the production of glucose [12] [13]. Therefore, the patient's postprandial BG level from test group is lower than the control group.

GI is an index that describes the human body's digestion and absorption rate, but BG responses to food. The testing food can be considered as low GI food when GI of this food is less than 55; it is medium GI food when GI index between 55 and 70; it is high GI food when GI more than 70 [11] [14]. According to the Food Glucose Production Index compiled by the Sichuan Provincial Nutrition Society, patients in the control group are given wet noodles as high GI foods (GI was 81.6). When these wet noodles enter the patient's gastrointestinal tract, it is digested easily by digestive enzymes and absorbed by intestinal mucosa, and then postprandial BG rise significantly. The study group is fed dry noodles made from wheat flour which GI is 46.0 . Therefore, it is considered as low GI food. After entering the patient's gastrointestinal tract, dry noodles are not easily digested by digestive enzymes and absorbed by the intestinal mucosa, so the BG level is low [11] [14] [15].

Starch is an important part of carbohydrate-based noodles, accounting for about $65 \%$ to $75 \%$ [14]. Studies have shown that patient eat higher carbohydrates, the higher BG level will be [16]. In this study, the patients in the control group not only take in thin, loose and noodle soup, but also soup containing starch. Their intake is two times of the patients in the study group. Therefore, the postprandial BG level is significantly higher than the study group.

The diet of T2DM patients need to limit the amount of carbohydrates in the staple food. When eating carbohydrate foods with the same calorie content, patients try to select low GI food which is digested slowly in the gastrointestinal tract. It is useful to control the BG and reduce the fluctuation of insulin [13] [16].

In addition, effective health education could not only improve the patient's 
ability to recognize their own diseases, but also change their bad living habits, promote their compliance with doctor's orders, effectively reducing BG. The study shows that the patients in the study group are better than the control group in monitoring BG, living patterns, and complying with doctor's orders. The difference is statistically significant $(P<0.05)$. The reason is that peer education as an objectively existing behavior, which is impacted by successful experience, speech persuasion, patients' physiological and psychological conditions. It could support the self-management of DM patients [17]. Peer leaders' treatment experience and suggestions are more likely to be accepted by the patients if they have been suffering from the same disease as these patients, which will lead to the improvement of self-efficacy, compliance of management, and control of postprandial BG [17]. Thom et al. illustrate that the pre- and postprandial BG levels in the study group are lower than those in the control group after peer education, for low-income patients [17].

Therefore, medical staff should conduct peer education on patients according to their actual conditions, which can effectively improve postprandial BG in patients with T2DM and improve self-management.

\section{Conclusion}

In summary, the breakfast and diabetes education modalities are improved for patients with T2DM, which have reduced 2hPBG effectively after breakfast, promoting the development of good living habits, and improving patient self-management and compliance. However, this study has shortcomings such as shorter intervention time and less sample size, which needs further verification. The sample size and effects of interventions at different time periods are looked forward to increasing in the future.

\section{Acknowledgements}

This study is supported by the Hubei Medical and Health Science and Technology Plan Project (2014-24).

\section{Conflicts of Interest}

The authors declare no conflicts of interest regarding the publication of this paper.

\section{References}

[1] World Health Organization (WHO) (2016) Global Report on Diabetes. Working Papers.

[2] Riantiningtyas, R.R. and Marliyati, S.A.M. (2017) Formulation of Flakes with Red Kidney Bean and Red Palm Oil as a Potential Instant Breakfast for Type 2 Diabetes. Jurnal Sains Kesihatan Malaysia, 15, 91-96.

[3] Jarvandi, S., Schootman, M. and Racette, S.B. (2015) Breakfast Intake among Adults with Type 2 Diabetes: Is Bigger Better? Public Health Nutrition, 18, 2146-2152. https://doi.org/10.1017/S1368980014002973

[4] Gong, H.L., Dai, L.M., Liu, Y., Fang, Y. and Hou, B.X. (2014) Effect of Hospit- 
al-Community-Family-Care on Diet Control in Patients with Type 2 Diabetes. Chinese Journal of Nursing, 49, 399-403. (In Chinese) https://doi.org/10.3761/j.issn.0254-1769.2014.04.003

[5] Jakubowicz, D., Wainstein, J., Ahren, B., Landau, Z., Bar-Dayan, Y. and Froy, O. (2015) Fasting until Noon Triggers Increased Postprandial Hyperglycemia and Impaired Insulin Response after Lunch and Dinner in Individuals with Type $2 \mathrm{Di}$ abetes: A Randomized Clinical Trial. Diabetes Care, 38, 1820-1826. https://doi.org/10.2337/dc15-0761

[6] American Diabetes Association (ADA) (2018) 5. Prevention or Delay of Type 2 Diabetes: Standards of Medical Care in Diabetes-2018. Diabetes Care, 41, S51-S54. https://doi.org/10.2337/dc18-S005

[7] Su, X.L., Qi, Y.M. and Zhou, S.H. (2016) Comparative Study of Formula 2 and Type 2 Diabetes Patients with Measured Resting Energy Expenditure. Chinese Journal of Clinical Nutrion, 24, 226-229. (In Chinese) https://doi.org/10.3760/cma.j.issn.1674-635X.2016.04.007

[8] Chinese Nutrition Society (2016) Chinese Dietary Guidelines. People's Medical Publishing House, Beijing, Vol. 9, 271-277. (In Chinese)

[9] Parillo, M., Giacco, R., Riccardi, G., Pacioni, D. and Rivellese, A. (1985) Different Glycaemic Responses to Pasta, Bread, and Potatoes in Diabetic Patients. Diabetic Medicine, 2, 374-377. https://doi.org/10.1111/j.1464-5491.1985.tb00655.x

[10] Ridner, E. and Di, S.A. (2015) Glycemic Index of Two Varieties of Pasta and Two Varieties of Rice. Archivos Latinoamericanos De Nutricion, 65, 79-85.

[11] Fan, G.S., Xu, D., Fu, Z.L., Xu, C.Y., Yang, R., Sun, B.G., et al. (2016) Research Progress of Glycemic Index. China Food Additives, 10, 56-68. (In Chinese)

[12] Zhong, F., Yokoyama, W., Wang, Q. and Shoemaker, C.F. (2006) Rice Starch, Amylopectin, and Amylose: Molecular Weight and Solubility in Dimethyl Sulfoxide-Based Solvents. Journal of Agricultural \& Food Chemistry, 54, 2320-2326. https://doi.org/10.1021/jf051918i

[13] Elinor, H., Francesco, S., Domenico, L., Inger, B. and Elin, O. (2011) A Novel Wheat Variety with Elevated Content of Amylose Increases Resistant Starch Formation and May Beneficially Influence Glycaemia in Healthy Subjects. Food \& Nutrition Research, 55, 401-410. https://doi.org/10.3402/fnr.v55i0.7074

[14] Sichuan Nutrition Society (2004) The Diet Tables of Glycemic Index. Compilation of Special Reports and Abstracts of the 5 th Member Congress and Academic Conference of Sichuan Nutrition Society, 4. (In Chinese)

[15] Yan, M.Y., An, Y.J., Bian, D.L. and Xing, Q.R. (2011) Glycemic Index and Application. Journal of Military Surgeon in Southwest China, 13, 902-903. (In Chinese) https://doi.org/10.3969/j.issn.1672-7193.2011.05.063

[16] Ji, Y.H., Ji, E.P., Young, J.C., Kap, B.H., Namsoo, C. and Wha, Y.K. (2013) Carbohydrate Intake Interacts with snp276G $>$ T Polymorphism in the Adiponectin Gene to Affect Fasting Blood Glucose, HbA1c, and HDL Cholesterol in Korean Patients with Type 2 Diabetes. Journal of the American College of Nutrition, 32, 143-150. https://doi.org/10.1080/07315724.2013.791795

[17] Thom, D.H., Ghorob, A., Hessler, D., De, V.D., Chen, E. and Bodenheimer, T.A. (2013) Impact of Peer Health Coaching on Glycemic Control in Low-Income Patients with Diabetes: A Randomized Controlled Trial. Annals of Family Medicine, 11, 137-144. https://doi.org/10.1370/afm.1443 